\title{
Tag retention, wound healing, and subsequent reproductive history of southern right whales following satellite-tagging
}

\author{
Peter B. Best ${ }^{1}$ \\ Mammal Research Institute, University of Pretoria, \% Iziko South African Museum, PO Box \\ 61, Cape Town 8000, South Africa; \\ Bruce Mate and Barbara Lager-Quist, \\ Marine Mammal Institute, Fisheries and Wildlife, Oregon State University, Hatfield Marine \\ Science Center, 2030 SE Marine Science Drive, Newport, Oregon 97365, U.S.A. \\ ${ }^{1}$ Corresponding author (e-mail peter.best@axxess.co.za).
}

\begin{abstract}
This paper presents data from 48 resightings of 16 southern right whales that were satellite-tagged on the South African coast in September 2001, up to and including 2012. Tag performance in terms of number of days with locations received was significantly higher in males than females, and lowest in cows with calves, and attributed to behavioral differences leading to variable degrees of antenna damage. Resightings occurred from 4 to $4,054 \mathrm{~d}$ after tagging: tags were retained in all whales seen within $27 \mathrm{mo}$, but were apparently shed in all but one individual seen within 36 mo of tagging. The exception was a whale that still had the tag present $11 \mathrm{yr}$ after tagging. Healing at the tag site occurred gradually and within $5 \mathrm{yr}$ of tagging (and $2 \mathrm{yr}$ after tag shedding). No significant difference in the subsequent frequency of calving was detected between 12 tagged and 382 untagged females photographed contemporaneously, and although statistical power was low, a $21 \%$ or greater reduction in calving rate in tagged females would seem incompatible with the observations. The death of one female $3 \mathrm{yr}$ after tagging was more likely attributable to a ship strike on an animal debilitated by a prolapsed uterus.
\end{abstract}

Key words: right whale, Eubalaena australis, satellite telemetry, South Africa, tag retention, wound healing, calving frequency.

Satellite tracking of any animal, but especially those that are otherwise difficult to access or cryptic in behavior such as a large whale species, is potentially an extremely powerful tool for studying its distribution and movements. Mysticete species on which such tags have already been deployed include bowhead whale, Balaena mysticetus (Mate et al. 2000; Heide-Jørgensen et al. 2003a, 2006; Quackenbush et al. 2010), northern right whales, Eubalaena glacialis and E. japonica (Mate et al. 1997, Baumgartner and Mate 2005, Wade et al. 2006), southern right whale, E. australis (Mate et al. 2011), blue whale, Balaenoptera musculus (Mate et al. 1999, Heide-Jørgensen et al. 2001a, Bailey et al. 2010), fin whale, B. physalus (Watkins et al. 1996, Heide-Jørgensen et al. 2003b, Mikkelsen et al. 2007, Cotté et al. 2009), minke whale, B. acutorostrata (Heide-Jørgensen et al. 2001b), humpback whale, Megaptera novaeangliae (Zerbini et al. 2006, 2011; Dalla Rosa et al. 2008; Lagerquist et al. 
2008; Garrigue et al. 2010; Hauser et al. 2010), and gray whale, Eschrichtius robustus (Mate and Urbán-Ramirez 2003). Because of the practical difficulties of attaching external devices to an animal with no pelage, a dynamic epidermis, and subject to hydrodynamic forces, all recent devices achieving longer attachment times have had to be invasive to a greater or lesser extent, raising concerns over potential tissue damage and infection. In some workshops, participants have suggested that a point of attachment just below the blubber/muscle interface or deeper may lead to longer attachment durations (Montgomery 1987, Weller 2008, Anonymous 2012), but placing an anchor accurately and consistently in this relatively narrow zone is clearly difficult, and over-penetration of the sharpened tip could increase the likelihood of subdermal tissue damage. All workshops (Montgomery 1987, Kraus et al. 2000, Weller 2008, ONR 2009, Anonymous 2012, Moore et al. 2013) have recommended posttagging studies, principally to evaluate tag retention and wound healing, but once the tag is lost or shed, locating the tagged individual for longer term studies to evaluate survival and reproductive success is obviously more difficult, especially when the population is large and migratory or offshore in habit. Thus, it is not surprising that there have been relatively few such longer term studies: Fujiwara (in Kraus et al. 2000) compared survival probabilities of 44 tagged and 275 untagged right whales in the North Atlantic, Best and Mate (2007) compared calving frequencies before and after tagging in seven satellite-tagged southern right whales, and Mizroch et al. (2011) studied the survival of seven radio-tagged humpback whales over 20-30 $\mathrm{yr}$ in the North Pacific. None of these studies found significant differences between tagged and untagged animals, but the samples in two of the studies were very small and none undertook (or published) any power analysis.

In September 2001, satellite transmitters were deployed on 21 southern right whales on the South African coast: the subsequent movements and resighting histories of some of these individuals have already been described (Best and Mate 2007, Mate et al. 2011). This population presents unusually favorable monitoring opportunities, since mothers with calves have been subject to annual photo-identification surveys carried out in a consistent manner since 1979, on which sighting probabilities have averaged $74.1 \pm 1.3$ (SE) \% (Brandão et al. 2011). Here we report observations on the processes of tag application, tag shedding, and wound healing up to eleven years post tagging, and compare reproductive histories to investigate whether any statistically significant differences can be detected between tagged and untagged females.

\section{Materials and methods}

The tags, equipped with Telonics ST-15 UHF Argos transmitters, were stainless steel cylinders $1.9 \mathrm{~cm}$ in diameter and $26.7 \mathrm{~cm}$ long designed to be almost completely subdermal, with a cross-bladed tip for penetration (Fig. 1). A rosette of thin, outwardly curved wires $(3.5 \mathrm{~cm}$ long, $0.9 \mathrm{~mm}$ diameter) was mounted just behind the tag head with two rosettes of outwardly curved metal strips, or petals $(0.6 \mathrm{~cm}$ wide and $3.2 \mathrm{~cm}$ long), immediately behind the row of wires. The petals were held flush with the tag body before deployment by layers of water-soluble starch tape. Behind the petals, the body of the tag was coated with a broad-spectrum antibiotic (Gentamycin sulphate) mixed in acetone with a long-dispersant methacrylate powder. In order to prevent inward migration, the posterior end of the tag was fitted with a $5 \mathrm{~cm}$ long Delrin endcap with two lateral extensions ("T-stopper") $0.9 \mathrm{~cm}$ wide, 
$1.5 \mathrm{~cm}$ long, and $0.7 \mathrm{~cm}$ thick; deep, flared wells protected the antenna and saltwater switch connections from damage caused by bending. A $13.5 \mathrm{~cm}$ long whip antenna made of $3 \mathrm{~mm}$ stainless steel cable was covered with plastic heat-shrink tubing and silver-soldered to the cap screw feed-through.

The tags were deployed in two batches, 16 in St. Sebastian Bay (on the south coast) on three days between 8 and 13 September (in a total of $19 \mathrm{~h}$ sea time), and five off Saldanha Bay (on the west coast) on five days between 21 and 26 September (in a total of $26 \mathrm{~h} 55 \mathrm{~min}$ sea time). Eight were deployed on females accompanied by calves-of-the-year (all in St. Sebastian Bay), five on females without calves, five on males and three on whales of undetermined sex. Tagging was carried out from a $6 \mathrm{~m}$ power boat (St. Sebastian Bay) or inflatable (Saldanha Bay), and whales were approached from behind and one side on a run that attempted to place the marksman as close as possible to the whale while it was moving slowly at the surface between dives. Tags were deployed from a $68 \mathrm{~kg}$ crossbow, with deployment distances from the tip of the crossbow to the whale ranging from 0.5 to $3 \mathrm{~m}(\bar{x}=1.9 \mathrm{~m})$. Observations of the tag location on the body and its degree of protrusion were also recorded (Table 1).

No systematic searches for tagged whales were made, and resightings arose incidentally from three main sources; annual photo-identification surveys by helicopter $(n=34)$, commercial boat-based whale-watching operations $(n=4)$, and independent research projects on the west coast in the vicinity of Saldanha and St. Helena Bays $(n=7)$. Because of the seasonal occurrence of right whales in South African waters, resightings occurred only in the months of September through January, with $39(81 \%)$ in October: the concentration of resightings in the latter month was also influenced by the timing of the annual aerial surveys, always set for October. These factors resulted in an obvious temporal discontinuity in the probability of resighting within any year, but in addition, the typical 3 yr calving interval of reproductively active females meant that every third year (when present with a calf) their probability of resighting would be higher than in other years. Because of this nonsystematic search effort and discontinuous probability of resighting, establishing the timing of events (such as the shedding of the tag) can only be approximated. When comparing the timing of events between individuals, a standardized terminology, $\mathrm{d} / \mathrm{mo} / \mathrm{yr}$ Post Tagging (PT) has been adopted.

Two principal methods are available for evaluating the possible effects of tag deployment on reproductive behavior; pre and posttagging comparisons of the same individual, and posttagging comparisons of tagged and untagged individuals.

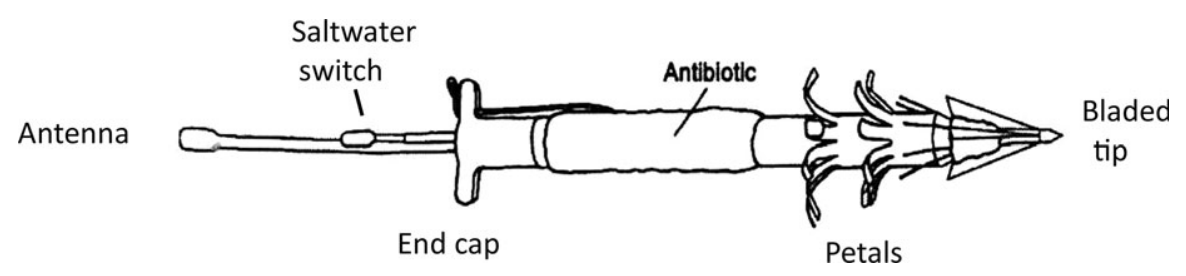

Figure 1. Diagrammatic representation of satellite tag deployed on southern right whales, South Africa, 2001 (from Mate et al. 2007; see text for dimensions). 
Table 1. Right whales satellite-tagged off South Africa, September 2001: details of tag deployment, tracking success, and tag situation at resightings. In column $2, \mathrm{~F}=$ female, $\mathrm{M}=$ male, $\mathrm{U}=$ unknown sex, and $\mathrm{M} / \mathrm{C}=$ mother with calf. $\mathrm{d} \mathrm{PT}=$ days posttagging? = inadequate view. Range refers to the estimated distance between the tip of the crossbow and the whale.

\begin{tabular}{|c|c|c|c|c|c|c|c|c|c|c|c|c|}
\hline \multirow[b]{2}{*}{ Tag \# } & \multirow[b]{2}{*}{$\begin{array}{l}\text { Sex or } \\
\text { reproductive status }\end{array}$} & \multirow[b]{2}{*}{ d PT } & \multicolumn{4}{|c|}{ Deployment } & \multicolumn{3}{|c|}{ Tracking success } & \multicolumn{3}{|c|}{ Resighting } \\
\hline & & & $\begin{array}{l}\text { Range } \\
(\mathrm{m})\end{array}$ & $\begin{array}{l}\text { Protruding } \\
\quad(\mathrm{cm})\end{array}$ & $\begin{array}{c}\text { Proportional } \\
\text { distance } \\
\text { from head }\end{array}$ & $\begin{array}{l}\text { Distance } \\
\text { from } \\
\text { midline } \\
(\mathrm{cm})\end{array}$ & $\begin{array}{l}\text { Days } \\
\text { tracked }\end{array}$ & $\begin{array}{c}\text { Mean \# } \\
\text { locations/ } \\
\text { day }\end{array}$ & $\begin{array}{c}\% \\
\text { rejected } \\
\text { locations }\end{array}$ & $\begin{array}{l}\text { Tag } \\
\text { seen }\end{array}$ & $\begin{array}{l}\text { Stopper } \\
\text { seen }\end{array}$ & $\begin{array}{c}\text { Antenna } \\
\text { seen }\end{array}$ \\
\hline 823 & $\mathrm{M} / \mathrm{C}$ & 0 & 3.0 & 9.0 & 0.67 & 20.5 & 25 & 1.8 & 9 & & & \\
\hline 824 & $\mathrm{U}$ & 0 & 3.0 & 4.0 & 0.50 & 10.0 & 0 & 0 & & & & \\
\hline \multirow[t]{3}{*}{825} & $\mathrm{U}$ & 0 & 2.5 & 2.5 & 0.55 & 10.0 & 38 & 2.8 & 23 & & & \\
\hline & & 2,235 & & & & & & & & No & & \\
\hline & & 2,962 & & & & & & & & No & & \\
\hline \multirow[t]{2}{*}{826} & $\mathrm{~F}$ & 0 & 3.0 & 0.0 & 0.50 & 5.0 & 36 & 1.0 & 11 & & & \\
\hline & & 36 & & & & & & & & Yes & Yes & No \\
\hline \multirow[t]{4}{*}{827} & $\mathrm{M} / \mathrm{C}$ & 0 & 3.0 & 4.0 & 0.50 & 20.0 & 27 & 2.1 & 22 & & & \\
\hline & & 33 & & & & & & & & Yes & Yes & No \\
\hline & & 1,130 & & & & & & & & No & & \\
\hline & & 2,589 & & & & & & & & No & & \\
\hline \multirow[t]{4}{*}{831} & $\mathrm{~F}$ & 0 & 1.0 & 3.0 & 0.50 & 15.0 & 35 & 0.8 & 32 & & & \\
\hline & & 1,117 & & & & & & & & No & & \\
\hline & & 2,225 & & & & & & & & No & & \\
\hline & & 3,318 & & & & & & & & No & & \\
\hline \multirow[t]{4}{*}{834} & $\mathrm{M} / \mathrm{C}$ & 0 & $0.5^{\mathrm{a}}$ & $5.0^{\mathrm{b}}$ & 0.50 & 5.0 & 0 & 0 & & & & \\
\hline & & 28 & & & & & & & & Yes & Yes & No \\
\hline & & 75 & & & & & & & & $\mathrm{Yes}^{\mathrm{c}}$ & $?$ & $?$ \\
\hline & & 1,127 & & & & & & & & No & & \\
\hline
\end{tabular}




\begin{tabular}{|c|c|c|c|c|c|c|c|c|c|c|c|c|}
\hline \multirow[b]{2}{*}{ Tag \# } & \multirow[b]{2}{*}{$\begin{array}{c}\text { Sex or } \\
\text { reproductive status }\end{array}$} & \multirow[b]{2}{*}{$\mathrm{d}$ PT } & \multicolumn{4}{|c|}{ Deployment } & \multicolumn{3}{|c|}{ Tracking success } & \multicolumn{3}{|c|}{ Resighting } \\
\hline & & & $\begin{array}{l}\text { Range } \\
(\mathrm{m})\end{array}$ & $\begin{array}{l}\text { Protruding } \\
\quad(\mathrm{cm})\end{array}$ & $\begin{array}{l}\text { Proportional } \\
\text { distance } \\
\text { from head }\end{array}$ & $\begin{array}{l}\text { Distance } \\
\text { from } \\
\text { midline } \\
(\mathrm{cm})\end{array}$ & $\begin{array}{l}\text { Days } \\
\text { tracked }\end{array}$ & $\begin{array}{c}\text { Mean \# } \\
\text { locations/ } \\
\text { day }\end{array}$ & $\begin{array}{c}\% \\
\text { rejected } \\
\text { locations }\end{array}$ & $\begin{array}{l}\text { Tag } \\
\text { seen }\end{array}$ & $\begin{array}{l}\text { Stopper } \\
\text { seen }\end{array}$ & $\begin{array}{l}\text { Antenna } \\
\text { seen }\end{array}$ \\
\hline \multirow{3}{*}{835} & & 3,322 & & & & & & & & No & & \\
\hline & $\mathrm{M} / \mathrm{C}$ & 0 & $0.5^{\mathrm{a}}$ & 5.0 & 0.40 & 7.5 & 0 & 0 & & & & \\
\hline & $\mathrm{F}$ & 1,101 & 20 & & & & & & 20 & No & & \\
\hline \multirow{2}{*}{836} & 1 & 385 & 2.0 & 2.0 & 0.67 & 15.0 & 81 & 2.8 & 20 & $?$ & & \\
\hline & & 1,485 & & & & & & & & No & & \\
\hline \multirow[t]{5}{*}{837} & $\mathrm{~F}$ & 0 & 2.0 & $6.5^{2}$ & 0.50 & 7.5 & 0 & 0 & & & & \\
\hline & & 1,098 & & & & & & & & No & & \\
\hline & & 1,860 & & & & & & & & No & & \\
\hline & & 2,954 & & & & & & & & No & & \\
\hline & & 4,054 & & & & & & & & No & & \\
\hline 838 & M & 0 & 1.5 & 4.0 & 0.67 & 5.0 & 66 & 1.7 & 12 & & & \\
\hline \multirow[t]{4}{*}{839} & $\mathrm{~F}$ & 0 & 3.0 & 4.5 & 0.50 & 30.5 & 119 & 1.7 & 18 & & & \\
\hline & & 1,129 & & & & & & & & No & & \\
\hline & & 3,324 & & & & & & & & No & & \\
\hline & & 3,326 & & & & & & & & No & & \\
\hline \multirow[t]{3}{*}{843} & $\mathrm{M} / \mathrm{C}$ & 0 & 3.0 & 4.5 & 0.50 & 40.5 & 39 & 3.5 & 25 & & & \\
\hline & & 36 & & & & & & & & Yes & Yes & $?$ \\
\hline & & 4,041 & & & & & & & & Yes & Yes & No \\
\hline \multirow[t]{2}{*}{847} & $\mathrm{M} / \mathrm{C}$ & 0 & 1.0 & 5.0 & 0.67 & 5.0 & 57 & 2.6 & 17 & & & \\
\hline & & 29 & & & & & & & & Yes & Yes & $?$ \\
\hline
\end{tabular}




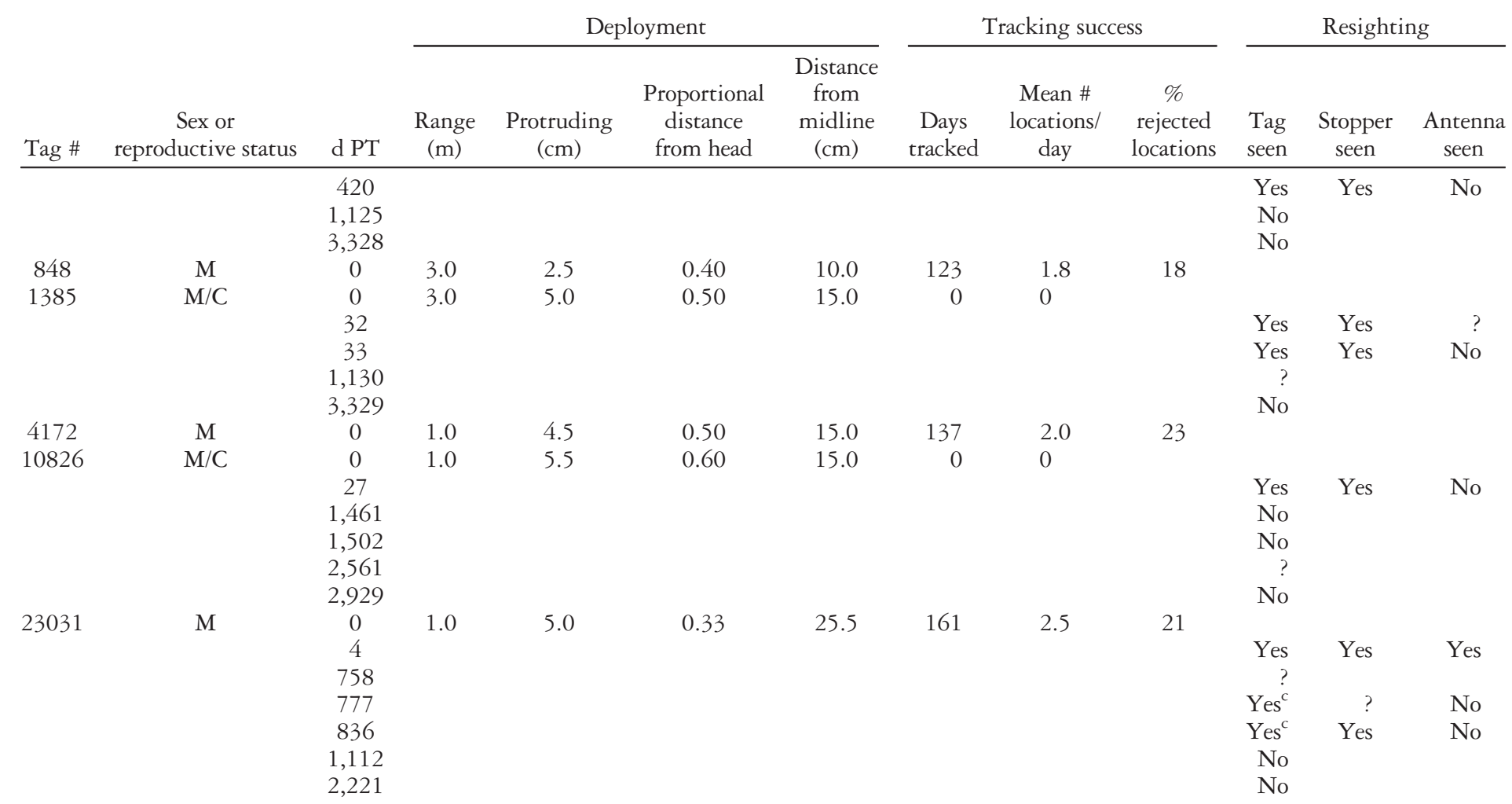




\begin{tabular}{|c|c|c|c|c|c|c|c|c|c|c|c|c|}
\hline \multirow[b]{2}{*}{ Tag \# } & \multirow[b]{2}{*}{$\begin{array}{l}\text { Sex or } \\
\text { reproductive status }\end{array}$} & \multirow[b]{2}{*}{ d PT } & \multicolumn{4}{|c|}{ Deployment } & \multicolumn{3}{|c|}{ Tracking success } & \multicolumn{3}{|c|}{ Resighting } \\
\hline & & & $\begin{array}{l}\text { Range } \\
(\mathrm{m})\end{array}$ & $\begin{array}{l}\text { Protruding } \\
\quad(\mathrm{cm})\end{array}$ & $\begin{array}{l}\text { Proportional } \\
\text { distance } \\
\text { from head }\end{array}$ & $\begin{array}{l}\text { Distance } \\
\text { from } \\
\text { midline } \\
(\mathrm{cm})\end{array}$ & $\begin{array}{l}\text { Days } \\
\text { tracked }\end{array}$ & $\begin{array}{c}\text { Mean \# } \\
\text { locations/ } \\
\text { day }\end{array}$ & $\begin{array}{c}\% \\
\text { rejected } \\
\text { locations }\end{array}$ & $\begin{array}{l}\text { Tag } \\
\text { seen }\end{array}$ & $\begin{array}{l}\text { Stopper } \\
\text { seen }\end{array}$ & $\begin{array}{c}\text { Antenna } \\
\text { seen }\end{array}$ \\
\hline 23034 & $\mathrm{~F}$ & $\begin{array}{c}0 \\
385 \\
1,489 \\
2,589\end{array}$ & 1.5 & 1.0 & 0.50 & 12.5 & 69 & 1.3 & 27 & $\begin{array}{c}\text { Yes }^{c} \\
\text { No } \\
\text { No }\end{array}$ & Yes & No \\
\hline 23037 & M & $\begin{array}{c}0 \\
1,506\end{array}$ & 1.5 & 4.0 & 0.40 & 10.0 & 64 & 0.7 & 13 & No & & \\
\hline
\end{tabular}

${ }^{\mathrm{a}}$ Range originally recorded as $<1 \mathrm{~m}$.

${ }^{\mathrm{b}}$ One of these two whales seen next day with T-Stopper flush with skin.

${ }^{c}$ Tag protruding. 
The former was the method used by Best and Mate (2007), and while it has the advantage of accounting for individual variation in reproductive behavior, it has the complication of potential maturation effects, i.e., unless the animal is of known age when tagged it is difficult to establish when its reproductive life began, and if the animal is with its first observed calf when tagged there is effectively no pretagging data available for comparison. This can reduce the already small sample size of individuals to test. The second method avoids this latter complication by using a common starting point for all individuals, i.e., for females tagged while accompanied by a calf $(n=7$, the photos of the eighth female with calf being too poor for matching), their subsequent reproductive histories have been compared with those of all other untagged females seen with a calf that year $(n=163)$. To increase the sample size, females tagged without a calf but subsequently seen with a calf have also been included $(n=5)$ : none had been seen earlier with a calf, so their subsequent reproductive histories have been compared with those of untagged females also seen for the first time with a calf in that year $(n=219)$. Because the two samples are independent they have subsequently been combined and reproductive rates expressed as the number of calves produced per year per female up to and including 2012.

To the extent that the nonappearance of a female with a calf could indicate mortality rather than a failure to reproduce, the above index in reality reflects both the individual's survival and its reproductive success.

In order to investigate whether the tagged whales had an inherently higher probability of being resighted, their pretagging sighting histories have been compared with those of untagged whales also seen in 2001, using the photo-identification surveys carried out annually since 1979 . Because this survey program concentrated on cow-calf pairs, the comparison has been confined to cows seen/photographed with calves in 2001, and their sighting rate expressed as the number of calves/year observed between first sighting and 2001.

\section{Results}

\section{Deployment-positioning of Tag and Tag Protrusion}

Tags were placed between an estimated one-third and two-thirds of the way back from the head, with $16(76 \%)$ between $40 \%$ and $60 \%$ of mid-length (Table 1). Most $(86 \%)$ were deployed on the whale's left side, and estimated distances of the tag from the midline varied from 5 to $40 \mathrm{~cm}(\bar{x}=14 \mathrm{~cm})$. Protrusion of the tag after deployment was estimated as $0-9 \mathrm{~cm}$, with a mean of $4.1 \mathrm{~cm}$. There was no significant correlation between estimated range and degree of tag protrusion $(r=-0.0986$, $t=-0.43$, two-tailed $P=0.6720)$.

Protrusion at this stage appeared to be only temporary. On 12 September, two partially albinistic females were tagged (at 1101 and 1200), with tags protruding 6.5 and $5 \mathrm{~cm}$, respectively. At 1149 on the next day a partially albinistic female was seen with a tag flush with the skin. Although the resighted individual was not identified, these were the only two partially albinistic females with calves that had been previously tagged, so it can be assumed that the tag must have migrated inwards within $24 \mathrm{~h}$ of being deployed. A similar observation was made at 1235 on 26 September, when two tagged whales were seen, both with tags flush with the skin. One of the pair had large white 

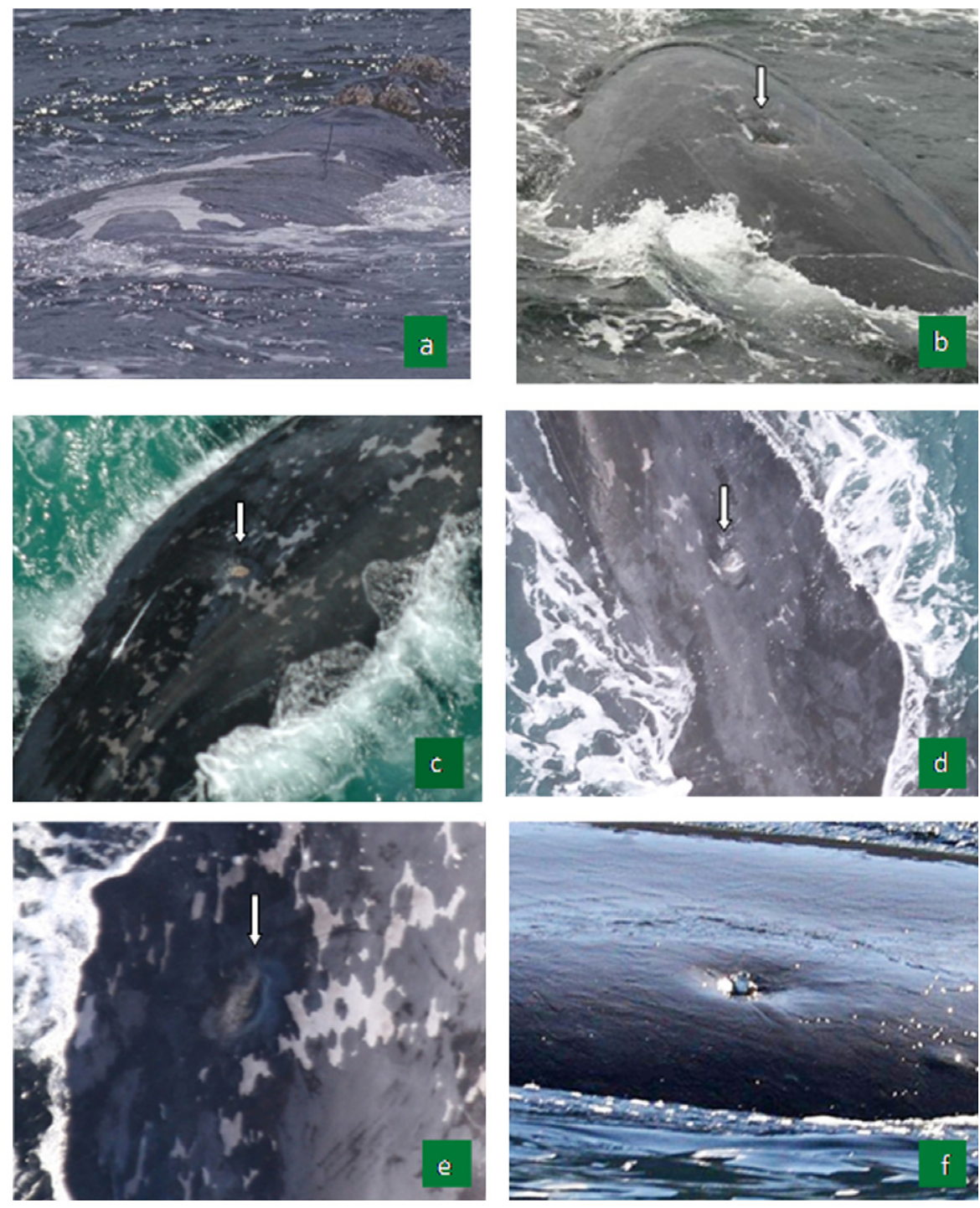

Figure 2. (a) Satellite-tagged right whale P23031 photographed $4 \mathrm{~d}$ PT, showing tag flush with skin; (b) satellite-tagged whale P837 photographed 1,098 d PT, tag site indicated by arrow; (c) satellite-tagged whale P10826 photographed 1,461 d PT, tag site indicated by arrow; (d) satellite-tagged whale P837 photographed 4,054 d PT, tag site indicated by arrow; (e) satellite-tagged whale P10826 photographed 2,929 d PT, tag site indicated by arrow; (f) satellite-tagged whale P843 photographed 4,041 d PT, note lateral extensions of end-cap intended to prevent inward migration.

dorsal blazes (Fig. 2a), and was identified as an individual tagged at 1237 on 22 September, when the tag was estimated to have been protruding about $5 \mathrm{~cm}$. The tag must have migrated inwards within at most $4 \mathrm{~d}$ after tagging. 


\section{Factors Affecting Tag Performance}

There was a significant difference among reproductive categories in the number of days for which each whale was monitored by satellite (one-way ANOVA $F=13.0909, P=0.0005)$. Eight females with calves were tracked for $0-57 \mathrm{~d}$ $(\bar{x}=18.6 \pm 7.7 \mathrm{SE})$, five females without calves for $0-81 \mathrm{~d}(\bar{x}=44.2 \pm 14.3 \mathrm{SE})$, and five males for $64-161 \mathrm{~d}(\bar{x}=110.2 \pm 19.4 \mathrm{SE})$. Whales tracked for one day or less comprised $50 \%$ of the cow-calf pairs and $20 \%$ of the females without calves. There was no significant correlation between the number of tracking days and the degree of tag protrusion $(r=-0.2261$, two-tailed $P=0.3252)$, position of tag along body $(r=-0.2528$, two-tailed $P=0.2689)$ or distance of tag from the midline $(r=0.3013$, two-tailed $P=0.1844)$.

Other indicators of tag performance, such as the number of locations received per day and the percentage of these of acceptable quality (see Mate et al. 2011 for definition), have been examined in relation to the variables degree of tag protrusion, position of tag along body and distance of tag from the midline (Table 1). The percentage of acceptable quality locations was not correlated with the degree of tag protrusion $(r=-0.2969$, two-tailed $P=0.2830)$, the relative position of the tag along the body $(r=-0.2789$, two-tailed $P=0.3142)$, or the distance of the tag from the midline $(r=0.3090$, two-tailed $P=0.2625)$. The number of locations per day was also not correlated with the degree of tag protrusion $(r=-0.1662$, two-tailed $P=0.4743)$, the position of the tag along the body $(r=0.5037$, two-tailed $P=0.0556)$ or the distance from the midline $(r=0.1935$, two-tailed $P=0.4895)$.

\section{Subsequent Resightings of Tagged Whales and Disappearance of Tag}

In total, there were 48 resightings of 16 identifiable tagged whales, and a single sighting of an unidentified tagged whale. Resightings occurred from 4 to $4,054 \mathrm{~d}$ PT, with obvious groupings at annual (and in some cases triennial) intervals (Fig. 3).

Tags were still present in all eight whales observed from 4 to $75 \mathrm{~d}$ PT (two of which were sighted twice), and in all three whales observed from 385 to approximately $430 \mathrm{~d}$ PT (one of which was recorded as starting to protrude). Only one tagged whale was observed between 777 and $836 \mathrm{~d}$ PT (twice), and the tag was still present on both occasions, though protruding. No tags were seen in any of the 13 whales observed (from one to four occasions) between 1,098 and 3,329 d PT, but in the two whales seen at 4,041 and 4,054 d PT, the tag was still present in the former. Tags were therefore retained in all whales seen within 27 mo of tagging, with the tag starting to protrude $1 \mathrm{yr}$ PT, and most tags disappearing by 36 mo PT, but with an outlier at 11 yr PT.

\section{Observations of Wound Condition}

Wound details that could be discerned when a tagged whale was resighted (and usually photographed) depended greatly on the source of resighting, principally because of the different ranges involved in aerial (ca. 100-150 m) and boat-based (ca. 20-30 m) observations. This has to be taken into account in the following section. Additionally, there appeared to be some individual variation in the healing process, so following the process over time in a small number of different individuals (enforced by the lack of any comprehensive data set for one individual) can obviously affect the conclusions. 


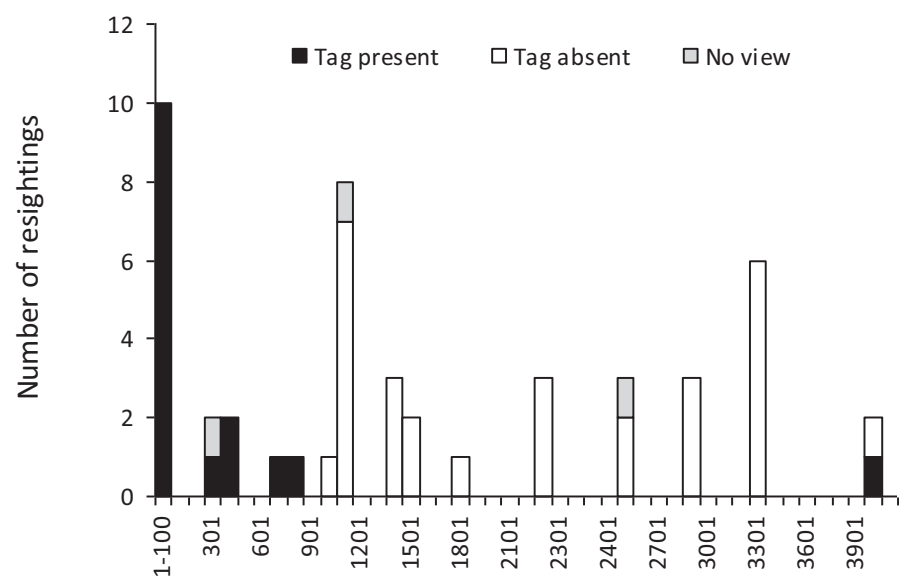

Days since tagging

Figure 3. Frequency of resightings of satellite-tagged right whales at $100 \mathrm{~d}$ intervals since tagging off South Africa, 2001-2012.

Tag sites in six whales observed from 27 to $75 \mathrm{~d}$ PT consisted of a circular shallow depression surrounding the tag and estimated (from the relative size of the tag) as about $15 \mathrm{~cm}$ in diameter. There was little sign of discoloration of the surrounding skin, little indication of cyamid infestation and/or granulation, and no signs of swelling.

In two other whales observed from 385 to $430 \mathrm{~d}$ PT, the depression surrounding the tag seemed to be larger (an estimated $25-30 \mathrm{~cm}$ in diameter), and its floor was extensively granulated and/or covered with cyamids (probably Cyamus erraticus). The blubber surrounding the depression appeared to be raised in a slight swelling in one case.

In the one whale photographed between 777 and $836 \mathrm{~d}$ PT, views were inadequate to examine wound condition, but no swelling was apparent around the tag site, from which the tag was protruding.

The tag site on five of the seven whales examined between 1,098 and 1,130 d PT appeared merely as a circular indentation in which the epidermis was lighter than the surrounding skin, but four of these were photographed from the air and the presence of granulation/scarring could not be discounted. A sixth whale washed ashore dead (see account below), and the wound was similar in conformation except that there was a central perforation corresponding to where the tag had been located. Granulation appeared to be absent, as were cyamids (although these may have been dislodged during stranding). The seventh whale was photographed from a boat, and the indentation included a central area of granulation (Fig. 2b). No swelling around the site of any of the wounds was seen.

Three of the four whales photographed 1,461-1,506 d PT carried similar wounds to those seen a year earlier, with the edges of the depression covered by lighter-colored epidermis surrounding a central area of granulation/cyamids (Fig. 2c). The tag site of the fourth whale (photographed from the air) seemed similar but with possible scarring on the anterior edge. In the single whale 
examined $5 \mathrm{yr}$ after tagging, the tag site was still recognizable from the characteristic surrounding depression but the wound had narrowed to a transverse slit, with greatly reduced central granulation.

From 2,221 d PT onwards, the majority $(71.4 \%, n=14)$ of tag sites were visible as indentations only, with the skin generally the same color as the remainder of the dorsal surface (Fig. 2d, e). In a few cases, some cyamids were also visible at the bottom of the indentation. At this stage the tag sites were sometimes not detected as such during aerial photography, and only after the individual had been identified as a satellite-tagged animal from its callosity pattern did a search of images reveal the tag site. Such sites were most obvious from their sunken relief when the back was exposed above water. None was associated with any swelling.

In the whale that retained the tag for 4,041 d, or just over $11 \mathrm{yr}$, the tag was situated at the base of a shallow indentation, estimated from the size of the tag end piece to be about $12-15 \mathrm{~cm}$ in diameter (Fig. 2f). The skin surrounding the tag seemed to be the same color as the rest of the dorsum, and cyamid infestation of the tag site was minimal. There were no obvious signs of swelling.

\section{Resighting History of Tagged Whales and Comparison with Untagged Whales}

Sixteen tagged whales were resighted up to and including 2012 (Fig. 4). The other five whales for which no posttagging histories are available include three males, one female and one of unknown sex: images of the female at tagging are too poor for matching, while the aerial surveys are principally directed at photographing adult females and accompanying calves so that the probability of resighting a tagged male is low. For example, of the 340 whales seen for the first time with a calf on surveys from 1992 to 2001, 90.3\% were seen again at least once during the ensuing $11 \mathrm{yr}$, while of the 43 whales photographed without a calf on the same surveys, $20.9 \%$ were

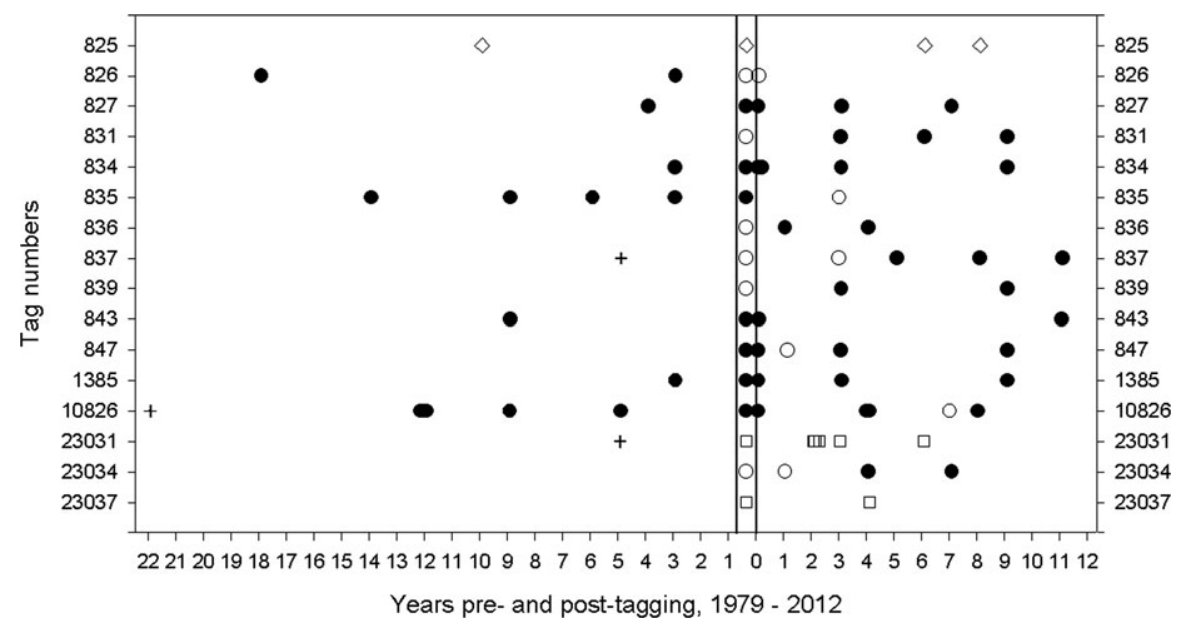

Figure 4. Pre- and posttagging sightings of right whales satellite-tagged off the South African coast in September 2001 (closed circle $=$ female with calf, open circle $=$ female without calf, open square $=$ male, cross $=$ calf, open diamond $=$ unknown sex). Status at tagging shown in vertical insert. 
seen again at least once during the same period: if those resighted with calves are removed (as was effectively done here), then the resighting rate of the latter group falls to only $8 \%$.

Ten of the tagged whales had been seen in earlier years. Two of these had been seen only as calves, and both were 5 yr old when tagged (one male, one female). Both were resighted after tagging, with the female producing its first observed calf at an age of $10 \mathrm{yr}$, close to the mean for this population $(6-13 \mathrm{yr}, \bar{x}=8.58 \mathrm{yr}$; Brandão et al. 2011). One individual was of unknown sex but was resighted twice without a calf and having not been seen as a mother over a sighting history of $19 \mathrm{yr}$ is likely to be male. All of the remaining seven individuals had been accompanied earlier by calves and so were presumably adult females.

One of these females, after producing at least five calves over $15 \mathrm{yr}$ before tagging, was found dead in the surf in 2004, from causes apparently unrelated to the tagging (see below). Only one of the remaining six females was not seen in years subsequent to tagging: this individual had only been seen with two calves over $18 \mathrm{yr}$ prior to tagging, and with an observed interval of $15 \mathrm{yr}$, suggesting that it was either a subfertile animal or one whose availability to the aerial survey program was reduced by some behavioral trait. Its failure to be resighted up to $10 \mathrm{yr}$ after tagging may therefore be of little significance. A similar explanation may account for the behavior of P843 that had an observed calving interval of 9 yr prior to tagging but was only seen with its next calf $11 \mathrm{yr}$ after tagging.

The distributions of posttagging calving rates in 12 tagged and 382 untagged females are quite similar (Table 2). The mean calving rates for tagged whales $(0.243 / \mathrm{yr}, 95 \%$ CI $0.189,0.297)$ and untagged whales $(0.246 / \mathrm{yr}, 95 \%$ CI 0.237

Table 2. Observed calving rates in right whales with and without satellite tags, South Africa, 2001-2012. Frequency of calving refers to the number of calves produced from the year of tagging onwards for both females tagged while accompanied by a calf and for all other untagged females seen with a calf in that tagging year, expressed per year at large (see text for details).

\begin{tabular}{ccc}
\hline \hline Frequency of calving & Tagged & Untagged \\
\hline 0.083 & 1 & 23 \\
0.091 & & 5 \\
0.111 & & 13 \\
0.125 & & 7 \\
0.143 & 1 & 17 \\
0.167 & 1 & 42 \\
0.182 & 1 & 14 \\
0.222 & 6 & 27 \\
0.25 & & 82 \\
0.273 & & 22 \\
0.286 & 1 & 22 \\
0.333 & & 59 \\
0.364 & & 10 \\
0.375 & 1 & 28 \\
0.429 & & 10 \\
0.5 & 12 & 1 \\
Total & & 382 \\
$\bar{x} \pm$ SE & $0.243 \pm 0.024$ & $0.246 \pm 0.005$
\end{tabular}


and 0.255$)$ were not significantly different $(t=0.12$, one-tailed $P=0.4523,392$ df). However, the small sample of tagged whales means the probability of detecting a significant difference is probably low: given the dubious value of estimating post hoc power levels (Hoenig and Heisey 2001), we have rather used the $95 \%$ confidence intervals of the observed effect size $(0.003,95 \%$ CI $-0.0493,0.0557)$ to determine the range of values with which the data are statistically compatible (Colegrave and Ruxton 2003, Trout et al. 2007). On this basis a mean calving rate for tagged individuals of 0.1937 (or lower), or a $21 \%$ (or greater) reduction in calving rate compared to untagged individuals, would not be consistent with the data.

\section{Mortality of Tagged Whale}

On 14 September 2004 an adult female southern right whale that had died at sea and was adrift in the surf, was reported at Grotto Bay $\left(33^{\circ} 30.08^{\prime} \mathrm{S}, 18^{\circ} 19.15^{\prime} \mathrm{E}\right)$ on the west coast of South Africa. When examined the whale was only partially stranded, but a small circular depression at about its mid-length was considered consistent in conformation and position with a possible satellite tag scar. Apart from photographs and some measurements no material was collected, the animal still being in the surf. The images and observations indicated that the whale had been hit by a ship before stranding, with one flipper partially severed, the rostrum broken and the baleen missing. The uterus had also prolapsed. The suspected tag site was recorded as healed with no sign of cyamid infestation, although there were cyamids clustered at the peduncle and on the lower jaw.

Photographs of the rostral callosity pattern were compared with the South African catalog and the animal identified as R87/54A, an adult female satellite-tagged with calf in attendance in St Sebastian Bay on the south coast on 13 September 2001. It had not been sighted since tagging.

\section{Pretagging History of Tagged and Untagged Whales}

The validity of the comparison of reproductive performance between tagged and untagged individuals relies on the assumption that the two groups were intrinsically similar in behavior. Although this might seem reasonable, previous attempts to test for differences in reproductive performance in whales following interventions such as biopsying have sometimes concluded that this assumption may not be entirely correct, and that there might be inadvertent selection for animals to tag/biopsy (Weinrich et al. 1991, Best et al. 2005). Such an effect could arise, for instance, if some individuals habitually have longer residence times in or are more frequent visitors to coastal waters and are therefore more likely to be encountered, both for tagging and in follow-up surveys. To the extent that this bias in availability can lead to apparently higher resighting rates and fewer longer-than-normal calving intervals in tagged than untagged individuals, it would tend to obscure any deleterious effects of tagging. However a comparison of pre-2001 calving rates for tagged and untagged females seen with calves in 2001 (excluding animals seen for the first time) was not consistent with this hypothesis (at least as it concerns adult females), the relevant calving rates being $0.261 / \mathrm{yr}(\mathrm{SE} \mathrm{0.034,n=6)}$ and $0.274 / \mathrm{yr}(\mathrm{SE} 0.007, n=164)$ respectively. 


\section{Discussion}

This paper documents tag shedding and subsequent wound healing from implantable satellite-monitored radio tags on southern right whales over an $11 \mathrm{yr}$ period. It demonstrates gradual healing of the tag site and similarities in calving rates between tagged and untagged whales, both historically (prior to tagging in 2001) and after tagging. None of the tagged whales appeared especially emaciated, however, such assessments are complicated by the fact that cows with calves become thinner as lactation progresses (Miller et al. 2011).

The differences in tag performance among reproductive categories were probably the result of differential damage to tag antennas and/or saltwater switches arising from variable degrees of physical contact between whales. Tags on mothers, which had the poorest overall performance, likely sustain the most damage due to the high degree of physical contact between calves and their mothers. The reason for the inferior performance of tags on females without calves compared to those on males is more difficult to explain, but if such females in coastal waters are the target of mating attempts (as documented by Best et al. 2003), it is possible that similar antenna damage is inflicted by courting males during the frequent episodes when the focal female lies inverted at the surface (Kraus and Hatch 2001). The likelihood of antenna malfunction as a primary cause of tag failure is heightened by the ex post facto finding that the flux used to solder the stranded wire cable antenna connection was not completely neutralized, leading to brittleness and susceptibility to damage (Mate et al. 2007). The manufacturing of the antenna and saltwater switch "cables" was subsequently changed to a crimp fit process as used in aircraft construction to avoid such issues.

The cessation of transmissions was not necessarily linked to internal migration of the tags, as the tag and T-Stopper were still visible on eight whales after their last location had been received (Table 1). We attribute the subsequent disappearance of most externally visible tags by about 36 mo to outward rather than inward migration because of (1) positive evidence of protrusion over time in three whales, (2) no evidence of loss of T-Stopper in any whale, and (3) the presence of an open penetrative wound in the stranded female (on the assumption that the act of stranding would be more likely to drive any externally visible tag further into the wound site rather than extract it). Nevertheless, definitive necropsies of tagged whales were lacking.

Evaluating the possible physical effects of the tagging on the whales is not straightforward. Observations of tag site condition inevitably concern only the superficial tissues surrounding the entry wound, with little insight into possible effects on deeper tissues, apart possibly from signs of swelling or depression of the surface. To that extent, the results outlined here do not suggest that deployment of the tag caused any significant long-term damage to the southern right whale integument, as evidenced by lack of swelling observed in all but one resighting, reduction in cyamid infestation over time in the tag site indentation, and repigmentation of the surrounding skin over time.

Based on the finding of a bent hypodermic needle in a right whale at necropsy, Moore et al. (2013) have suggested that the chronic depressions around tagging sites (as seen here) may reflect the subsidence of skin and blubber as a result of the destruction of underlying muscle tissue caused by it moving past any portion of the tag that penetrates the blubber/muscle interface. The thickness of the dorsal blubber in 12 female right whales with calves on the South African coast measured by ultrasound in September 1999 ranged from about 16 to $26 \mathrm{~cm}$ with a mean of $19.82 \mathrm{~cm}$ : by November this had reduced to about 
13.5 to $21 \mathrm{~cm}$ with a mean of 17.24 in 19 females with calves (Miller et al. 2011). This implies that at full vertical penetration, and assuming a $30 \mathrm{~cm}$ long tag less $1 \mathrm{~cm}$ stopper, approximately $3-13 \mathrm{~cm}(\bar{x}=9.2 \mathrm{~cm})$ of tag might have penetrated beyond the blubber/muscle interface at tagging: by November the penetration may have increased by another $2.6 \mathrm{~cm}$. More realistically, if tags were placed at up to 30 degrees from the vertical, this penetration might in practice be reduced to $0-9.1 \mathrm{~cm}(\bar{x}=5.3 \mathrm{~cm})$ at tagging, increasing to 4.1$11.6 \mathrm{~cm}(\bar{x}=7.9 \mathrm{~cm})$ by November. This would potentially seem sufficient to cause some damage to underlying muscle, although how much may depend in part on the tag location and how much muscle movement occurs relative to the overlying blubber: the needle discussed by Moore et al. (2013) was lodged in the dorsolateral aspect of the abdomen about $60 \%$ of the body length from the tip of the snout, whereas most tags in this study were situated anterior to this and closer to the midline. As flexion of the body (in small cetaceans at least) is confined to the caudal one third to one quarter of the body (Pabst 1993), it seems possible that shear effects at the blubber/muscle interface are less when the tag is placed further forward on the body. Robbins et al. (2013) describe broad swellings at tag sites that were more prevalent when the tag was located on the lower flank of humpback whales than on the upper flank/dorsal fin area, lending some support to the suggestion that the site of attachment of a penetrating tag may be an important factor in the development of tissue reaction.

Although the penetration hypothesis for the formation of the depressions seems reasonable, there may also be a contribution from the loss of tissue physically displaced by the tag. Robbins et al. (2013) report one instance of a tissue plug emerging from a tagged humpback whale and being shed between 12 and $15 \mathrm{~d}$ PT, followed about three weeks later by the formation of a divot or depression. However the volume of the tag used in this study (excluding barbs) was only $76 \mathrm{~cm}^{3}$, so this contribution may be quite small. W. Medway thought that tag depressions were likely due to the rupture of fat cells in the blubber layer that do not regenerate and noted these are common features in line-entanglement or propeller-strike injuries that do not penetrate beyond the blubber layer into muscle. ${ }^{2}$

If the presence of a depression does principally represent trauma to the underlying tissues, its persistence even when the tag has apparently been shed could indicate that the damage is permanent, although it could also indicate that remnants of the attachment device (such as splines or petals) have been retained despite the main body of the tag being expelled. There are a variety of tag designs and manufacturers: separation of one such tag type from its anchoring device has been observed in live whales (Robbins et al. 2013), and Moore et al. (2013) found barbs from another tag type's attachment device still in situ in a whale necropsied $19 \mathrm{~d}$ after being tagged (but an unknown interval after the tag detached). However, Robbins et al. (2013) recorded subsequent shedding of tag anchors, in one case about a year after the tag itself was shed. In our data a depression has persisted for at least 6 (and possibly 8) yr after the tag was lost (PTT 847), and no tagged animals have yet "lost" their depression, suggesting that unless tag remnants are consistently retained for that length of time the depressions may more likely be permanent than temporary. The depression surrounding the tag retained for $11 \mathrm{yr}$ did not appear to be any more prominent than in those

\footnotetext{
${ }^{2}$ Personal communication from William Medway, Director, Clinical Laboratory, University of Pennsylvania School of Veterinary Medicine, New Bolton Center Hospital, 382 West Street Road, Kennett Square, PA 19348, November 2002 [deceased 2009].
} 
that had been retained for $<3$ yr, so any damage inflicted may be relatively localized and not necessarily aggravated by tag retention.

The stranding of the Grotto Bay female inevitably raises concerns that the event could have been related to its earlier tagging. This cannot be completely discounted because no real attempt was made to necropsy the animal to establish the cause of death, but the balance of evidence suggests this is unlikely. Although it is impossible to determine whether the ship strike occurred before or after death, the fact that the animal had a prolapsed uterus suggests that it was probably already incapacitated and so more vulnerable to being struck by a vessel. Adult right whales with a prolapsed uterus have been seen on at least four other occasions in South African waters, two of which were alive at the time of sighting and two were stranded dead: the sex of a fifth animal reported floating dead with reproductive organs everted could not be confirmed. The etiology of this condition in cetaceans is unknown, but in other animals, such as cattle, prolapse of the uterus invariably occurs immediately after or within several hours of parturition, when the cervix is open and the uterus lacks tone (Gilbert 2011). The female R87/54A had been photographed with calves in 1987, 1992, 1995, 1998, and 2001, and given its usual calving interval (3 yr) would have been expected to calve again in 2004. As the peak of the calving season is in August (Best 1994), the circumstances are certainly consistent with the female experiencing postnatal uterine prolapse, leading ultimately to its demise.

In conclusion, this study affirms the value of long-term monitoring of tagged animals and documents wound healing over time as well as similarity in calving rates between tagged and untagged whales. This paper does not discuss other possible effects of tagging, such as discomfort or pain associated with tag retention, because there are currently no means of assessing these conditions for cetaceans. In the absence of such assessment methods and in light of the findings in this study, we agree with the recommendations of some previous workshops (e.g., Anonymous 2012) that the conservation value of a project should be taken into consideration when determining whether to tag an endangered species, and believe that tag designs should be scaled to study goals and thus strive to minimize potential effects.

\section{Acknowledgments}

The authors thank those who contributed images and data to the paper, especially Yvonne Kamp and Wilfred Chevill (Dyer Island Cruises), Dave Hurwitz (Simon's Town Boat Company), Jaco Barendse, Meredith Thornton, Ingrid Peters, Simon Elwen, Desray Reeb, Michael Meÿer, and Leszek Karczmarski. Those involved in the actual tagging have been acknowledged in Mate et al. (2011). PBB acknowledges the financial support for the survey program from the National Research Foundation, South Africa, and the International Whaling Commission. Tagging was funded by grants to BRM from the U.S. National Marine Fisheries Service, Office of Naval Research and gifts from donors to the Oregon State University Marine Mammal Program, and carried out under a permit issued to PBB by the South African Department of Environmental Affairs and Tourism in terms of Regulation 58 of the Marine Living Resources Act (no. 18 of 1998) dated 10 January 2001. Oregon State University's Institutional Animal Care and Use Committee approved this research, under permit \#2284. All subsequent field work was undertaken in terms of permits issued annually to PBB by the Department of Environmental Affairs (and its predecessors) in terms of the Marine Living Resources Act, 1998 (Act no. 18 of 1998) and its predecessors. 


\section{References}

Anonymous. 2012. Report of the workshop on the satellite tracking of southern right whales in Australian waters, Melbourne, Australia, 22-23 November 2012. Australian Marine Mammal Centre, Kingston, Australia. 23 pp.

Bailey, H., B. R. Mate, D. M. Palacios, L. Irvine, S. J. Bogard and D. P. Costa. 2010. Behavioural estimation of blue whale movements in the northeast Pacific from statespace model analysis of satellite tracks. Endangered Species Research 10:93-106.

Baumgartner, M. F., and B. R. Mate. 2005. Summer and fall habitat of North Atlantic right whales (Eubalaena glacialis) inferred from satellite telemetry. Canadian Journal of Fisheries and Aquatic Sciences 62:527-543.

Best, P. B. 1994. Seasonality of reproduction and the length of gestation in southern right whales Eubalaena australis. Journal of Zoology, London 232:175-189.

Best, P. B., and B. R. Mate. 2007. Sighting history and observations of southern right whales following satellite tagging off South Africa. Journal of Cetacean Research and Management 9:111-114.

Best, P. B., C. M. Schaeff, D. Reeb and P. Palsbøll. 2003. Composition and possible function of social groupings of southern right whales in South African waters. Behaviour 140:1469-1494.

Best, P. B., D. Reeb, M. B. Rew, P. Palsbøll, C. Schaeff and A. Brandão. 2005. Biopsying southern right whales, their reactions and effects on reproduction. Journal of Wildlife Management 69:1171-1180.

Brandão, A., P. B. Best and D. S. Butterworth. 2011. Monitoring the recovery of the southern right whale in South African waters. Paper SC/S11/RW18 submitted to the International Whaling Commission Workshop on the Assessment of Southern Right Whales, Buenos Aires, Argentina, 13-16 September 2011.

Colegrave, N., and D. G. Ruxton. 2003. Confidence intervals are a more useful complement to nonsignificant tests than are power calculations. Behavioral Ecology 14:446-450.

Cotté, C., C. Guinet, I. Taupier-Letage, B. Mate and E. Petiau. 2009. Scale-dependent habitat use by a large free-ranging predator, the Mediterranean fin whale. Deep-Sea Research I 56:801-811.

Dalla Rosa, L., E. R. Secchi, Y. G. Maia, A. N. Zerbini and M. P. Heide-Jørgensen. 2008. Movements of satellite-monitored humpback whales on their feeding ground along the Antarctic Peninsula. Polar Biology 31:771-781.

Garrigue, C., A. N. Zerbini, Y. Geyer, M. P. Heide-Jørgensen, W. Hanaoka and P. Clapham. 2010. Movements of satellite-monitored humpback whales from New Caledonia. Journal of Mammalogy 91:109-115.

Gilbert, R. O. 2011. Uterine prolapse and eversion: Introduction. In C. M. Kahn, S. Line and S. E. Aiello, eds. The Merck veterinary manual. Ninth edition. Merck Sharp \& Dohme Corp., Whitehouse Station, NJ. Available at http://www.merckmanuals.com/vet/.

Hauser, N., A. N. Zerbini, Y. Geyer, M. P. Heide-Jørgensen and P. Clapham. 2010. Movements of satellite-monitored humpback whales, Megaptera novaeangliae, from the Cook Islands. Marine Mammal Science 26:679-685.

Heide-Jørgensen, M. P., L. Kleivane, N. Øien, K. L. Laidre and M. V. Jensen. 2001a. A new technique for deploying satellite transmitters on baleen whales: Tracking a blue whale (Balaenoptera musculus) in the North Atlantic. Marine Mammal Science 17:949-954.

Heide-Jørgensen, M. P., E. S. Nordøy, N. Øien, et al. 2001b. Satellite tracking of minke whales (Balaenoptera acutorostrata) off the coast of northern Norway. Journal of Cetacean Research and Management 3:175-178.

Heide-Jørgensen, M. P., K. L. Laidre, $\varnothing$. Wiig, et al. 2003a. From Greenland to Canada in ten days: Tracks of bowhead whales, Balaena mysticetus, across Baffin Bay. Arctic 56:21-31.

Heide-Jørgensen, M. P., L. Witting and M. V. Jensen. 2003b. Inshore-offshore movements of two fin whales Balaenoptera physalus tracked by satellite off West Greenland. Journal of Cetacean Research and Management 5:241-245. 
Heide-Jørgensen, M. P., K. L. Laidre, M. V. Jensen, L. Dueck and L. D. Postma. 2006. Dissolving stock discreteness with satellite tracking: Bowhead whales in Baffin Bay. Marine Mammal Science 22:34-45.

Hoenig, J. M., and D. M. Heisey. 2001. The abuse of power: The pervasive fallacy of power calculations for data analysis. The American Statistician 55:19-24.

Kraus, S. D., and J. J. Hatch. 2001. Mating strategies in the North Atlantic right whale (Eubalaena glacialis. Journal of Cetacean Research and Management (Special Issue 2). 237-244.

Kraus, S., C. Quinn and C. Slay. 2000. A workshop on the effects of tagging on North Atlantic right whales. Unpublished report, New England Aquarium, Boston, MA. 14 pp.

Lagerquist, B. A., B. Mate, J. G. Ortega-Ortiz, M. Winsor and J. Urbán-Ramirez. 2008. Migratory movements and surfacing rates of humpback whales (Megaptera novaeangliae) satellite tagged at Socorro Island, Mexico. Marine Mammal Science 24:815-830.

Mate, B. R., and J. Urbán-Ramirez. 2003. A note on the route and speed of a gray whale on its northern migration from Mexico to central California, tracked by satellite-monitored radio tag. Journal of Cetacean Research and Management 5:155-157.

Mate, B. R., S. L. Nieukirk and S. D. Kraus. 1997. Satellite-monitored movements of the northern right whale. Journal of Wildlife Management 61:1393-1405.

Mate, B. R., B. A. Lagerquist and J. Calambokidis. 1999. Movements of North Pacific blue whales during the feeding season off southern California and their southern fall migration. Marine Mammal Science 15:1246-1257.

Mate, B. R., G. K. Krutzikowsky and M. H. Winsor. 2000. Satellite-monitored movements of radio-tagged bowhead whales in the Beaufort and Chukchi Seas during the latesummer feeding season and fall migration. Canadian Journal of Zoology 78:1168-1181.

Mate, B., R. Mesecar and B. A. Lagerquist. 2007. The evolution of satellite-monitored radio tags for large whales: One laboratory's experience. Deep Sea Research II 54:224-247.

Mate, B. R., P. B. Best, B. A. Lagerquist and M. H. Winsor. 2011. Coastal, offshore, and migratory movements of South African right whales revealed by satellite telemetry. Marine Mammal Science 27:455-476.

Mikkelsen, B., D. Bloch and M. P. Heide-Jørgensen. 2007. A note on movements of two fin whales (Balaenoptera physalus) tracked by satellite telemetry from the Faroe Islands in 2001. Journal of Cetacean Research and Management 9:115-120.

Miller, C. A., D. Reeb, P. B. Best, A. R. Knowlton, M. W. Brown and M. J. Moore. 2011. Blubber thickness in right whales Eubalaena glacialis and Eubalaena australis related with reproduction, life history status and prey abundance. Marine Ecology Progress Series 438:267-283.

Mizroch, S. A., M. F. Tillman, S. Jurasz, et al. 2011. Long-term survival of humpback whales radio-tagged in Alaska from 1976 through 1978. Marine Mammal Science 27:217-229.

Montgomery, S., ed. 1987. Report on the 24-26 February 1987 workshop to assess possible systems for tracking large cetaceans. Prepared for U.S. Marine Mammal Commission. U.S. Department of Commerce NTIS Report PB87-182135. 53 pp.

Moore, M., R. Andrews, T. Austin, et al. 2013. Rope trauma, sedation, disentanglement, and monitoring-tag associated lesions in a terminally entangled North Atlantic right whale (Eubalaena glacialis). Marine Mammal Science 29:E98-E113.

ONR (Office of Naval Research). 2009. Final workshop proceedings for cetacean tag design workshop, Arlington, Virginia, 16-17 March 2009. Office of Naval Research Marine Mammal and Biological Oceanography Program, Arlington, VA. 18 pp.

Pabst, D. A. 1993. Intramuscular morphology and tendon geometry of the epaxial swimming muscles of dolphins. Journal of Zoology, London 230:159-176.

Quackenbush, L. T., J. J. Citta, J. C. George, R. J. Small and M. P. Heide-Jørgensen. 2010. Fall and winter movements of bowhead whales (Balaena mysticetus) in the Chukchi Sea and within a potential petroleum development area. Arctic 63:289-307.

Robbins, J., A. N. Zerbini and N. Gales, et al. 2013. Satellite tag effectiveness and impacts on large whales: Preliminary results of a case study with Gulf of Maine humpback whales. 
Paper SC/65a/SH05 submitted to the Scientific Committee of the International Whaling Commission, June 2013.

Trout, A. T., T. J. Kaufmann and D. F. Kallmes. 2007. No significant difference ... says who? American Journal of Neuroradiology 28:195-197.

Wade, P., M. P. Heide-Jørgensen, K. Shelden, et al. 2006. Acoustic detection and satellitetracking leads to rare concentration of endangered North Pacific right whales. Biology Letters 2:417-419.

Watkins, W. A., J. Sigurjónsson, D. Wartzok, R. R. Maiefski, P. W. Howey and M. A. Daher. 1996. Fin whale tracked by satellite off Iceland. Marine Mammal Science 12:564-569.

Weinrich, M. T., R. H. Lambertsen, C. S. Baker, M. R. Schilling and C. R. Belt. 1991 Behavioural responses of humpback whales (Megaptera novaeangliae) in the southern Gulf of Maine to biopsy sampling. Report of the International Whaling Commission (Special Issue 13):91-97.

Weller, D. W. 2008. Report of the large whale tagging workshop convened by the U.S. Marine Mammal Commission, U.S. National Marine Fisheries Service, 10 December 2005, San Diego, CA. Contract Report to U.S. Marine Mammal Commission. 32 pp.

Zerbini, A. N., A. Andriolo, M. P. Heide-Jørgensen, et al. 2006. Satellite-monitored movements of humpback whales Megaptera novaeangliae in the southwest Atlantic Ocean. Marine Ecology Progress Series 313:295-304.

Zerbini, A. N., A. Andriolo, M. P. Heide-Jørgensen, et al. 2011. Migration and summer destinations of humpback whales (Megaptera novaeangliae) in the western South Atlantic Ocean. Journal of Cetacean Research and Management (Special Issue 3):113-118. 